\title{
4 \\ Public health, hygiene and social activism
}

\section{Thomas D'haeninck, Jan Vandersmissen, Gita Deneckere and Christophe Verbruggen}

In 1910, the Dutch physician Pieter Eijkman published L'internationalisme médical. ${ }^{1}$ In his introduction he referred to the Germanborn British physician August Schuster, who one year earlier, at the XVIe Congrès international de Médecine in Budapest (1909), strongly expressed the need for a coordination of the almost countless and often competing international efforts in the field of medical science and healthcare. ${ }^{2}$ Based on a typology of 30 categories, Eijkman listed 199 medical organisations and saw his extensive overview as a first step towards the establishment of an organisation of international organisations. In his overview, Eijkman praised three initiatives taken or supported by Belgians. The first was the Union internationale des Patronages, founded in Belgium by Henri Jaspar, secretary of the Commission royale des Patronages de Belgique. The union stressed the importance of health and hygiene, but went beyond purely medico-scientific practices by widening its scope to child protection, patronage of detained prisoners and ways of helping beggars and vagabonds. The second was the Concours pour un Remède contre la Maladie du Sommeil, an international prize installed in 1906 by King Leopold II, until 1908 sovereign of the Congo Free State (CFS). Sleeping sickness (human trypanosomiasis) was a devastating epidemic that in the first decade of the twentieth century ravaged entire populations, in particular in British Uganda and the CFS. King Leopold II turned to researchers of the Liverpool School of Tropical Medicine and awakened wider medical attention to sleeping sickness with the installation of a two hundred thousand franc prize for the discovery of a cure, thus cunningly presenting 
himself on the world stage as a humanist and philanthropist, not as the aggressive exploiter he really was (see Chapter 3, p. 104). ${ }^{3}$ The third initiative was the Association générale des Ingénieurs, Architectes et Hygiénistes municipaux de France, Algérie-Tunisie, Belgique, Suisse et Grand-Duché de Luxembourg, of which the main objectives were to link the engineer's 'art' to the precious skills of the municipal hygienist and to enhance international dissemination of knowledge about sanitary techniques and public works through, among other things, the journal La technique sanitaire et municipale. ${ }^{4}$

L'internationalisme médical hints at the importance of international influences on Belgian medicine and the intertwinement of Belgian social and medical initiatives in transnational dynamics. The (partially) Belgian contributions to medical internationalism mentioned by Eijkman connect to the leitmotivs of this chapter. We argue that the emergence of public healthcare in Belgium cannot be seen apart from cross-border exchanges, scientific innovations, social reform ambitions but also inter- and intra-imperial dynamics. Although Belgian history of medicine and public health is clearly intertwined with dynamics that go beyond the borders of states, it has, however, often been studied within a national framework, focusing on an urban context ${ }^{5}$ and on processes of institutionalisation and professionalisation. ${ }^{6}$ Recent research also emphasises that physicians were involved in transnational dynamics that went beyond their professional discipline. ${ }^{7}$ Cross-border dynamics between physicians and medical associations were part of a wider trend of transnational circulation of intellectual and cultural goods in the second half of the nineteenth century. The emergence of so-called transnational spheres can be seen as a catalyst for the formation of many scientific disciplines, expertise and ideological frameworks. ${ }^{8}$ Thorough research into cross-border dynamics on public health policies and practices is lacking for the Belgian case, which is striking since scholars have been indicating the strong intertwinement of Belgian history with international dynamics in the nineteenth and twentieth century. ${ }^{9}$ Sources such as L'internationalisme médical are an ideal point of departure to include them.

At the end of the eighteenth century a modern view on public health and social medicine emerged. Due to the growing awareness that many diseases had socio-economic origins, physicians started 
to collect information on the (urban) environment, searched for measures for the improvement of living conditions and advised policymakers on medical campaigns, prevention strategies and healthcare initiatives. In that way, physicians were drawn into a dynamic that seems to go beyond the scope of the individual body. ${ }^{10}$ They increasingly felt the urge to advocate for better living conditions and social change too. ${ }^{11}$ This process is referred to as the medicalisation of society. During the nineteenth century selfproclaimed experts with medical backgrounds perceived, diagnosed and declared social problems as if they were illnesses. ${ }^{12}$ Historians therefore share the view that physicians must be considered as a driving force for social change in the nineteenth and twentieth centuries. The formation of medical professions and related scientific specialisms had wider repercussions, which also influenced society in general.

Physicians, however, were not the only advocates for social change and progress. Their growing social commitment cannot be dissociated from upcoming philanthropic and reformist advocacy networks. ${ }^{13}$ The medicalisation of society was strongly intertwined with both the overall scientification of society and the rationalisation of dealing with the social question on a pan-European scale. ${ }^{14}$ Medical internationalism as described by Eijkman and Schuster and the medicalisation of society coincided with the formation of transnational reformist networks and the internationalisation of the social question. ${ }^{15}$ Hence, in this contribution we look at the social activism of medical doctors and hygienists in a twofold manner: first, as part of scientific and intellectual movements from which emerges the field of social medicine; second, as an essential formative element in the construction of expertise within reformist and social movements. We consider it impossible to make a rigid a priori distinction between science, knowledge and expertise. Whether knowledge is classified as expertise is ultimately premised on recognition as such by other actors in the field. We define expertise as forms of knowledge that are based on scientific ways of reasoning, while contributing to political and societal discussion and activism. Also, methodologically social and scientific movements can be addressed in a single manner, as both are constituted through collective action beyond borders. ${ }^{16}$ We therefore do not investigate social reformers and experts in local or national isolation, but we consider them as 
actors in a global field of discourse and practice. Such an actororiented approach reveals the ways in which experts set in motion global processes of knowledge exchange and transformation, which ultimately fuelled processes of scientific discipline formation based on relationships of mutual recognition, support and mobility across boundaries. With regard to the nineteenth- and twentieth-century colonial empires (including Belgium) these dynamics manifested themselves on an inter- and intra-imperial scale. In this chapter we therefore widen the scope by including public health measures implemented in Congo.

This chapter consists of four parts, which will be structured in a chronological way. The first part starts in the late eighteenth century and focuses on the emergence of 'scientific medicine' and the growing awareness that the study of many diseases could not be separated from the socio-economic context in which they originated. The second part discusses the impact of new bacteriological theories and insights on public health questions in the 1870s, linking social medicine more profoundly to applied sciences and preventive healthcare; social medicine became increasingly entangled with other reformist movements. The third part deals with the further development of social hygiene and the rise of eugenics, national health protection and the improvement policies in the interwar period. Finally, the fourth part re-evaluates the period after 1960 when national public health systems were strongly questioned, local community health centres emerged in the wake of 1968 and medical activism went increasingly beyond borders.

These four periods strongly overlap with what Pierre-Yves Saunier calls four different 'circulatory regimes' in the field of social reform and social policy. Saunier identified a first regime in the early nineteenth century, when the social question is defined in different places by observation of local conditions in relation to urbanisation and industrialisation processes. ${ }^{17} \mathrm{~A}$ second regime emerged at the end of the nineteenth century, when processes of specialisation in social knowledge led to the emergence of institutions and disciplines, as exemplified by the typology given by Eijkman in L'internationalisme médical. Cross-border dynamics and transnational circulation of knowledge became essential features of the process of discipline formation. ${ }^{18}$ In the interwar period, a third regime arrived when (new) institutions ambitiously searched for 
universal norms and standards for social policies, professions and practices, which were believed to lead to the 'well-being of humanity throughout the world'. ${ }^{19}$ The League of Nations became an important actor within this field of social policy and many prewar epistemic communities became further institutionalised. ${ }^{20}$ The fourth and last period is characterised by the presence of influential global players such as the World Health Organization (WHO), the emergence of new social movements and new international nongovernmental organisations (INGOs) devoted to social medicine and global public health, on the one hand, and advocates of more efficiency and privatisation, on the other. ${ }^{21}$

\section{The physician and the social question}

The emergence of a modern view on public health and social medicine dates back to the end of the eighteenth century. At the turn of the century, the interest in epidemiological research boomed. ${ }^{22}$ There was a growing awareness that many diseases were caused by bad living conditions and baleful socio-economic influences, urging physicians to plea for the improvement of the urban environment. Also, it was a widely held view that illnesses caused disasters and poverty and therefore undermined the (physical) strength and viability of both the individual and the state. In that way, physicians were drawn into a dynamic that went beyond the scope of the individual body ${ }^{23}$ and strongly stimulated a professional sense of belonging. ${ }^{24}$ In addition to the growing 'professional' interest physicians showed for social determinants, the ratio of physicians per capita increased in the course of time. Between 1831 and 1940 the number of physicians in Belgium more than tripled in proportion to the population. ${ }^{25}$ All of these factors lead to the enhanced social position of physicians ${ }^{26}$ and stimulated a process that is often referred to as the 'medicalisation of society': during the nineteenth century self-proclaimed experts coming from medical backgrounds perceived, diagnosed and declared social problems as if they were illnesses. ${ }^{27}$

Medical doctors in Belgium - as in other countries in Western Europe - became more and more convinced that the improvement of public health could not only be achieved via medico-technical 
and infrastructural innovations or scientific discoveries, but also by initiating, developing and steering social policies. A number of physicians pleaded for sanitation measures to be taken on a wide scale, and suggested actions that had to encourage personal and public hygiene and prevent epidemics. They reached an audience of fellow medical professionals, policymakers, but also members of the working class. Their ambitions strongly overlapped with initiatives taken by philanthropists and social reformers. Until the 1870s, these groups must be seen as strongly intertwined because they fought for the same social causes, met each other in learned societies such as the Académie royale des Sciences, des Lettres et des Beaux-Arts de Belgique and wrote for and/or read the same journals (e.g. Le Progrès). ${ }^{28}$ However, medical societies had emerged already in the 1820s in urban centres such as Brussels (Société des Sciences médicales et naturelles de Bruxelles, 1822), Ghent (Société de Médecine de Gand, 1834) and Antwerp (Société de Médecine d'Anvers, 1834). ${ }^{29}$ The differences between these private associations and newly founded public institutions such as the Académie royale de Médecine de Belgique (1841) were minimal, both with regard to their membership and the recommendations they made to the Belgian government and local authorities. ${ }^{30}$

The case of Adolphe Burggraeve, a practising surgeon and professor of anatomy and surgery at the State University of Ghent, illustrates the emergence of a modern type of professionalised physician who used his medical training in his search for social reform measures (Figure 4.1). Burggraeve was renowned for his innovative treatment of wounds and fractures. His elegant style of presenting preparations appealed both to a scientific and a wider audience. ${ }^{31} \mathrm{In}$ 1835 he was appointed as professor of anatomy at his alma mater in Ghent, where in 1828 he had obtained a degree in medicine with a thesis on syphilis. Burggraeve belonged to an engaged urban elite. As a member the Académie royale de Médecine de Belgique and the Société Huet, ${ }^{32}$ and as a co-founder of both the Société de Médecine de Gand (1834) and the Société royale d'Histoire naturelle de Gand (1851), he was rooted in several associations that incarnated the changing spirit of the time.

Especially the Société de Médecine de Gand offered a platform where Burggraeve and fellow academics, hospital staff and military physicians discussed both medical innovations and measures 


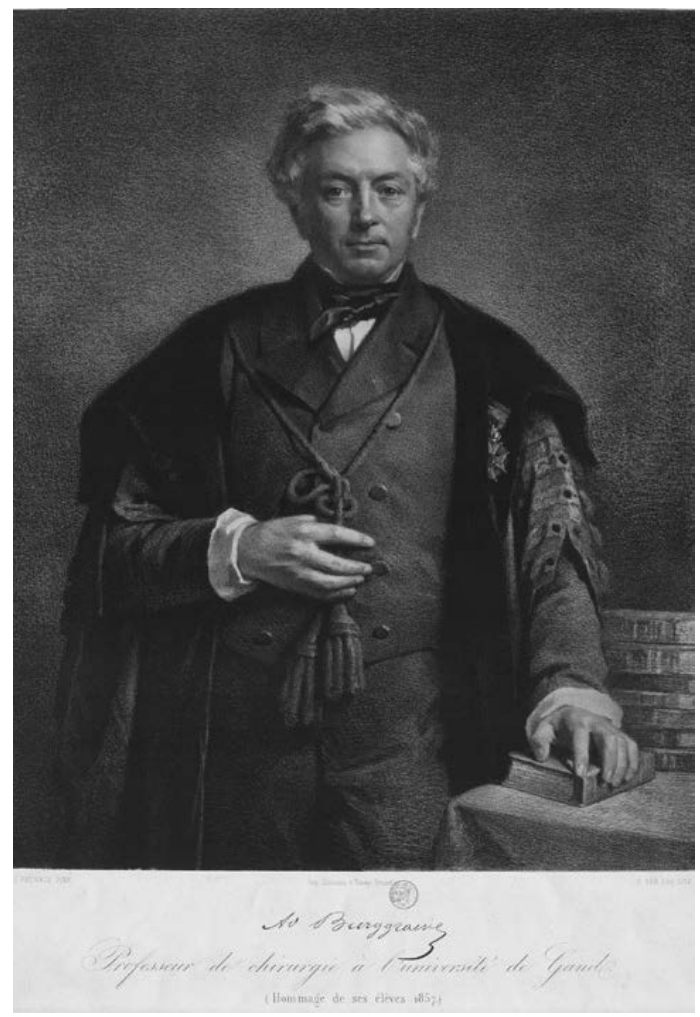

Figure 4.1 Portrait of Adolphe Burggraeve.

to improve urban living conditions. ${ }^{33}$ They collected and published leaflets and handbooks on infections, epidemics and venereal diseases and on social issues such as food provision, the installation of public toilets or the softening of sickening smells. Moreover, they advised the Belgian government and local authorities on health policies and made suggestions for the improvement of the industrial environment. One of the most prominent studies in this field was written in 1845 by Daniel Mareska and Jean-Julien Heyman. Their investigation of the labour conditions and moral and physical situation of the workers employed in Ghent's cotton mills ${ }^{34}$ stimulated further inquiries but also initiated social policies. ${ }^{35}$ In the 1860 s, plagues of cholera struck several neighbourhoods in Ghent. Relying on the recommendations 
he found in the old report of Mareska and Heyman, Burggraeve took action with a drastic sanitation of the Batavia quarter. This workingclass neighbourhood, known as an 'urban furuncle', was demolished and rebuilt. ${ }^{36}$ The reuse of urban space would also shape new opportunities: the university reached an agreement with city authorities to build a prestigious Institut des Sciences (1883) on terrain that had been cleared. ${ }^{37}$

Burggraeve and his fellows at the Société de Médecine de Gand illustrate that the role physicians played in the development of public healthcare went beyond the scope of the individual body or the neutrality of their scientific training. The rise of public health resulted directly from the growing social commitment of physicians. By advocating social change and progress, their medical expertise could hardly be dissociated from upcoming philanthropic and reformist advocacy networks or political movements. Physicians in Belgium are therefore not to be regarded as neutral: they claimed a social position and influenced decision-making processes. Especially the upcoming progressive wing ${ }^{38}$ within the Belgian Liberal Party functioned as an ally for social physicians: the political programme proposed by the 'progressisten' for tackling the bad living conditions of the working class focused on improved housing, better nutrition and accessible education. ${ }^{39}$ Hence, the fact that Adolphe Burggraeve participated in the elections for Ghent City Council in 1858 and got elected for the Liberal Party was by no means an exception. ${ }^{40}$ Physicians of Burggraeve's kind were embedded in contemporary ideological discussions and as a group of expert professionals they became both an instrument for and a force behind the gradual expansion of the state and its social policies. ${ }^{41}$ In consequence, the rise of public healthcare was a process of negotiation between medical professionals and state officials, whereby the difference between the physician and the politician was sometimes paper-thin. ${ }^{42}$

It must be stressed that in nineteenth-century Belgium the development of public health initiatives was first and foremost entrusted to local medical societies, authorities and institutions. The image of the Belgian night-watch state is related to the relative absence of interventions by the national state itself, at least up till the 1890s. However, the growing social engagements of physicians were limited to the local context. Many transnational connections between reform-minded citizens were established. The increased transnational 
interlinking between learned societies, where the social question is defined in different places by observation of local conditions in relation to the urbanisation and industrialisation processes, has been identified by Pierre-Yves Saunier as the first circulatory regime. Clergy, political activists, entrepreneurs, academics and politicians exchanged words and experiences in the North Atlantic space. ${ }^{43}$ In absence of INGOs, international congresses became the most important form of 'scientific internationalisation' in the early and mid nineteenth century. ${ }^{44}$ They were the venues par excellence for scientists, administrators, politicians, artists and others to meet and exchange ideas. Several Belgian physicians took leading roles at these events, but none as prominent as Adolphe Burggraeve. At the second meeting of the Association internationale pour le Progrès des Sciences sociales, held in Ghent in 1863, he presented his model for the ideal working-class quarter: a clean and healthy neighbourhood with many hygienic facilities and infrastructure for childcare and education. ${ }^{45}$ His plans were influenced by models in London and Mulhouse, which were also discussed at the association's events. In a similar vein, these models linked the housing question of the working class to savings, mutual support and popular education. In his speech, Burggraeve grasped the opportunity to highlight the information on the situation in Ghent collected by his colleagues and himself and to criticise the small progress made by local politicians when it came to improving the workers' living environment. The 'battalions of disease and death' in Ghent were believed to contrast strongly with the situation in Mulhouse. ${ }^{46}$ These international gatherings were not just fructifying meeting places for fellow socio-medical experts to exchange new ideas and practices. More so, here, an epistemic community was in the making. However, the congresses also offered a platform that strengthened the expert's image and offered him an opportunity to build personal networks with fellow reform-minded elites. Burggraeve's international engagements made sure that his voice was heard on a local and national level. His reputation as a leading man within the international scientific elite increased his influence in policymaking processes: by reporting facts (information politics) he fostered change and by relying on his cross-border network while evoking foreign best practices, he had a considerable impact on the ways like-minded people would lobby for and advocate social change. ${ }^{47}$ 


\section{Applied sciences and preventive healthcare}

The establishment of the Ghent Institut des Sciences was a direct result of the growing sociopolitical role physicians claimed, but the construction of modern scientific laboratories inspired by the German polytechnical schools in several Belgian university cities also marked changing views on medical knowledge, the physician's professional identity and public healthcare. In Liège, Leuven and Brussels similar institutions were built, inspired by model institutes in Heidelberg, Bonn and Berlin. In this new infrastructure experience and education were linked together (see Chapter 5, p. 185). ${ }^{48}$ This maelstrom of building works was strongly supported by the first Belgian minister for education, the liberal Pierre van Humbeeck, who provided government funding for universities to modernise their scientific infrastructure. The investments of the state in modern science and laboratories indicate the shift from the local to the national level, which the Belgian liberals were trying to carry through, at least in the educational field, during the (short) period they were in power (1879-84). The models of the polytechnic schools of Dresden and Berlin were widely discussed at the Congrès international de l'Enseignement held in Brussels in 1880 and inspired the present elite educators and policymakers and certainly also members of the Ligue de l'Enseignement belge such as Van Humbeeck. ${ }^{49}$ The influence went beyond architecture: the German scientific innovations were fiercely discussed in Belgian magazines, many Belgian professors like Héger and Frédéricq established firm ties with German colleagues and German scientific journals became important models. ${ }^{50}$

The new insights obtained between 1870 and 1890 are part of what is generally called the Pasteurian or bacteriological revolution. They stimulated the physician's training and interdisciplinary research, which resulted in several scientific innovations, the improvement of diagnostics, cures and prevention strategies and the establishment of the laboratory as part of the physician's infrastructure. ${ }^{51}$ The new university infrastructures not only left their mark on academic achievements, in Ghent, Leuven and Liège they were also used by the provincial authorities. In the absence of a Ministry of Public Health and given the local fragmentation of hygienic initiatives, these provincial authorities would, from the 
1890s onwards, develop public laboratories for bacteriology. By the turn of the century provincial institutes were established in Liège, Mons, Namur and Brussels. Both the academic and the provincial laboratories would provide public services such as the inspection of potable water, the distribution of sera against infectious diseases and bacteriological diagnosis of cholera, diphtheria, tuberculosis and rabies. Local authorities, physicians, medical societies and veterinarians could make use of the services of these laboratories free of charge. An imagery of commitment to public service was cultivated by the medical professionals operating these laboratories, such as Ernest Malvos, Martin Herman or Achille Haibe. ${ }^{52}$

The bacteriological revolution had a strong impact on the social role of physicians and public health questions too, linking social medicine more profoundly to applied sciences. More than merely advising policymakers on healthcare issues, physicians were employed by the government to implement hygienic measures. The private elite practitioners of the 1850 s, rooted in philanthropic circles, slowly made space for public healthcare professionals. By the 1880s, local Belgian governments had taken over many of the medical services that were traditionally provided by private practitioners, denominations and beneficence houses. The number of physicians working in governmental service significantly rose and they provided medical service in working-class districts, prisons, schools, etc. ${ }^{53}$ This was of major influence for the professional development of physicians in general and healthcare experts and hygienists in particular. ${ }^{54}$ The institutionalisation of medical professions went hand in hand with the centralisation of social policies and healthcare provision. Due to the foundation of the Superior Health Council (Conseil supérieur de la santé) (1849), the Royal Society of Public Health (Société royale de médecine publique) (1876) and medical journals such as Le Scalpel or Le Mouvement hygiènique, local public medical services and the national healthcare agenda became more aligned and coordinated. The campaigns and measures to improve public health became more extensive and no longer focused solely on problem solving but also on prevention. Public spaces with a high risk for raising epidemics or infections were closed and disinfected when possible. Medical checks were made mandatory for risk groups such as prostitutes, children, miners, etc. Nevertheless, the degree of state intervention in public health remained a contentious political 
issue, which divided the liberal party between hesitant conservative liberals - advocates of the nightwatchman state - and their more interventionist progressive colleagues. ${ }^{55}$

Hence, the most far-reaching preventive health measures, such as the establishment of medical inspection services for public schools, occurred in the liberal strongholds of Brussels (1874), Antwerp (1882) and Ghent (1896). ${ }^{56}$ Here school hygiene was brought to the attention of policymakers due to the alliance of progressive (liberal) politicians and politically active physicians. The physician Eugène Janssens played a vital role in the development of Brussels' health services, ${ }^{57}$ and his pioneering work in the $1870 \mathrm{~s}$ was presented as a successful example by like-minded physicians in Antwerp, Ghent, Liège and Charleroi. Soon after, Janssens founded a service of medical inspection in public schools in Brussels as part of the city's centralised health service (1874); the Antwerp physician Victor Desguin presented Janssens's model and ideas to the Société de Médécine d'Anvers. Moreover, as a member of Antwerp City Council and later also as alderman for education, Desguin would plead for the improvement and modernisation of the local healthcare system, with special attention for children and education. The networks of these physicians went beyond the borders of the Belgian nation state. Both Desguin and Janssens participated in the Congrès international de l'Enseignement (Brussels, 1880) where a section was dedicated to the matter of school hygiene. Two years later, Desguin established a medical school inspection in Antwerp, which he considered a model to be promoted actively abroad. ${ }^{58} \mathrm{At}$ the sixth international hygiene and demography congress (Vienna, 1887), Desguin presented the Antwerp model. ${ }^{59}$ The medical school inspection had to highlight the city's modern, science-based educational policy. In general, these services came about when liberals were in power and were used as propaganda against the Catholics. The medical school inspection only had the authority to medically check the children of public schools. Catholic schools did not benefit from these centralised medical services and were therefore framed as unhealthy and unhygienic. ${ }^{60}$

Preventive medical campaigns were also initiated by private activists and organisations. The fight against alcohol was fought by (army) physicians, clergymen and teachers (rather than by local or national authorities), who joined forces and founded private 
temperance societies in the late 1870s. Until 1889 no licence was needed for opening drinking establishments in Belgium. The first restrictive laws were voted only around 1900, and the Comité national antialcoolique was founded in 1912. The majority of antialcohol campaigners were rooted in urban progressive Catholic milieus, while a minority was socialist or claimed to be apolitical. ${ }^{61}$ The anti-alcohol movement found an ally in the women's rights movement. The Ligue belge du Droit des Femmes strongly believed that women could play a role in solving the problem of alcohol abuse. Wives were direct victims of the drunkenness of their husbands. Hence, feminists such as Marie Parent claimed that women had the important task to stop men from excessive drinking. ${ }^{62}$

More than a pure medical issue caused by social factors, alcoholism was perceived in Belgium as a problem of the individual resulting from a lack of awareness and willpower. The Ligue patriotique contre l'Alcoolisme was founded in 1879 by three physicians, Louis Martin, Hippolyte Barella and Théodore Belval. Their main focus was to spread anti-alcohol propaganda and establish local temperance societies throughout the country. The Ligue was successful. After the violent strikes of 1886 , the number of societies rapidly increased. ${ }^{63}$ They campaigned, among other things, via physicians who published both scientific works as well as practical leaflets that informed the population about the dangers of alcoholism and countered prejudices and superstitions with scientific facts. One key work was De alcohol in't licht der wetenschap, written by the physician Alfred De Vaucleroy, in which he disaffirmed with scientific experiments the popular beliefs that alcohol stimulates the digestive system or has healing properties (see Chapter 9, p. 339). He was actively involved in the transnational networks of the temperance movements and discussed his views at many of the Congrès internationaux contre l'abus des boissons alcooliques. Although his thoughts were well perceived by the international audience of alcohol experts, De alcohol in't licht der wetenschap was illustrative for the particular position of Belgium in the fight against alcohol. In contrast to protestant countries, many Belgian reformers were not in favour of total abstinence. They rather plea for moderation, by raising awareness and banning distilled drinks in general and absinthe in particular. 
In the Congo, preventive medicine followed the same dynamics of specialisation enhanced by transnational exchange of knowledge (see Chapter 3, p. 104). However, this occurred with some delay in comparison with things happening in Belgium. Understandably, this has to do with the fact that participation of Belgians in expansionist projects in Africa started only in 1876 . The CFS, founded by King Leopold II in 1885 in the margins of the Berlin Conference, was a one-man business in many ways, in which the Belgian state did not participate officially. No wonder that it mobilised but a small body of medical experts and provided scanty means for the development of a service médical (founded in 1888). ${ }^{64}$ The Leopoldian exploitation economy was dependent on private concessionary companies, investing, inter alia, in the construction of railways. These companies recruited no more than a few doctors, mainly to keep their white staff healthy. They undertook little action to protect the health of African and Asian labour forces, and certainly did not take prevention measures involving the rest of the population. In Belgium, the development of tropical hygiene and healthcare came late and one may say that it happened in an unstructured way, certainly when compared with countries with a much older imperial past such as France, where 'colonial' hygiene was shaped by provincial military institutions belonging to the navy; or the United Kingdom, which took advantage of its maritime medical tradition while at the same time relying on experience in combating epidemics in colonial India and the rest of the empire, thus leading, at the end of the nineteenth century, to the creation of schools for tropical hygiene and medicine in Liverpool and London. ${ }^{65}$

Nevertheless, in Belgium during the last quarter of the nineteenth century there was a gradual professionalisation in tropical hygiene and healthcare. In this respect, we should emphasise the importance of transnational knowledge exchanges through four channels: first, the international congresses on colonial hygiene and acclimatisation, where Belgians matched their experiences in Congo against those of other empires; second, a new intellectual 'colonial' sociability, comprising the geographical societies of Brussels and Antwerp, the Institut national de Géographie and the Société (royale) belge d'Etudes coloniales, which popularised and distributed knowledge in the fields of colonial hygiene and healthcare via lectures, courses, journals and books, thereby using information accumulated through 
an extensive network of relationships with similar societies abroad; third, the CFS's medical apparatus, consisting of Belgian and foreign staff, who initially managed a few poorly equipped sanatoria in the Lower Congo and focused exclusively on white state officials, but eventually also had a medical laboratory in Leopoldville, and from 1906 onwards, received support from a school of tropical medicine in Brussels, equipped with a bacteriological laboratory; fourth, inter-imperial knowledge exchange in combating major epidemics such as sleeping sickness, smallpox, leprosy and malaria, leading to prevention and vaccination campaigns, which initially focused on the white coloniser, but later on, when the human catastrophe was at its height and could no longer be ignored, became also oriented towards the African population. ${ }^{66}$

To understand Belgian appreciation of hygiene in an African context during the 'installation' phase of Leopoldian rule, one has to split up the concept into two complementary types: 'travel hygiene' and 'residential hygiene'. However, in the early years of Belgian presence, the first type prevailed, as exploration was at the heart of the African enterprise. The literature produced in the 1870s and 1880s primarily aimed at making European explorers survive the 'hostile' environment they had to cross, focusing on 'healthy' rules of conduct for white males while cruising the African rivers, the Maxim gun in hand ... As more and more people were faced with death - especially when the Free State's first, unprepared agents were establishing stations for permanent residence - attention shifted to 'residential hygiene'. This included health education for state officials, guidelines for building houses, laying emphasis on good aeration of the premises, inspired by studies that highlighted the impact of climate on the health of Europeans in Africa. The explorer Jérôme Becker illustrates this shift at a Berlin congress on colonial hygiene in 1886. In his speech he stressed the importance of physical training, clothing, balanced food and drinks and taking precautions against heat, cold and humidity. ${ }^{67}$ From the 1890s onwards the discussion became more emphatically medical, with an increased participation of physicians in public debate and more pronounced attention given to linking fieldwork to laboratory research, and ultimately to prevention campaigns. Gustave Dryepondt's career illustrates the various aspects of this transition period in a tropical context very well. 
Born in Bruges in 1866, Dryepondt graduated in medicine at the University of Brussels in 1890. The very same year he was recruited as physician to join the Van Kerckhoven expedition, initially destined to 'pacify' the eastern part of the Congo Basin, but known in later years as a violent imperialist attempt by the Leopoldian regime to gain access to the Nile Basin. During a stop in Leopoldville, Dryepondt was instructed to give medical aid to the white agents in this increasingly important station that gave direct access to the Upper Congo. Health reasons withheld him from continuing his work for the expedition, but in Leopoldville he lay the foundations of a small hospital. After a three-year stay in Congo, Dryepondt returned to Belgium in 1893 to recuperate. He immediately valorised his newly acquired medical knowledge, becoming an energetic speaker at learned societies, in particular the Société belge d'Etudes coloniales, where in 1894 he started the first medical courses for Belgians destined for a career in Congo. The content of his lessons was integrated in a Guide pratique hygiénique et médical du voyageur au Congo, issued by the administration of the CFS, on behalf of which Dryepondt served as conseiller médical. Dryepondt paid particular attention to climatic conditions. For many years Dryepondt's guide had a major impact on the life of Belgian agents in Congo. In fact, the guide became the second part of the collective work Manuel du voyageur et $d u$ résident au Congo, published by the Société belge d'Etudes coloniales in 1897. Every 'colonist' was expected to read this book. ${ }^{68}$ Dryepondt returned to Africa several times, both as a physician and as an administrator of colonial companies. Eventually he started pleading in favour of creating a Belgian school for tropical medicine following the British example. For this purpose, he established contacts with foreign experts, mainly at international congresses. Dryepondt shifted his attention to a more medical approach of tropical hygiene and healthcare. He became an advocate of introducing a professionalised organisation of the medical services in Congo as well as of establishing a medical laboratory in Leopoldville. It should be stressed that only in the post-Leopoldian period did he become really interested in the hygienic conditions of the African populations, supporting large-scale prevention campaigns. ${ }^{69}$ As Mertens and Lachenal have stressed, with the Belgian takeover of Congo the international significance of the 
sleeping sickness in particular served as a leverage, at the national level, for the profession of tropical medicine to obtain support within the state. Moreover, in the interwar period physicians such as Jérôme Rodhain and Jean E. van Campenhout contributed to the embedding of Belgian knowledge in an international sphere of expertise, taking a prominent role in the coordination of the fight against sleeping sickness and other epidemics through the League of Nations Health Organization (LNHO). ${ }^{70}$ Several contributions stress the international dimension of medical care, highlighting the growing influence of pharmaceutical multinationals and international health organisations. Such internationalism, moreover, was not limited to the European mainland. Medicine in the Belgian Congo, as Sokhieng Au makes clear, cannot be understood without acknowledging the competing presence and influence of American Protestant missions in the region. ${ }^{71}$

\section{National health protection and the well-being of the state and its citizens}

At the turn of the twentieth century and especially after the First World War, medicine became the social science par excellence. The Polish-French medical doctor Petre Trisca wrote in 1923 that 'there is no one better than the doctor to observe society, the physician is urged by his professional training to penetrate into all environments and to see everything. He truly understands the economic state of the country, the psychology of the various social classes, the moral diseases that use the energies, the physical diseases that destroy the body. ${ }^{72}$ Trisca's words reflected the growing awareness that there was a close relation between social and economic progress and public health. Therefore, physicians and policymakers were convinced that social medicine should be more than providing public healthcare, it should also be searching for ways to protect and improve national health. This resulted in the emergence of new scientific medical disciplines, domains and practices like eugenics, craniology, pre-marital check-ups, birth control for disabled people, periodic medical examination, the sterilisation of abnormalities and social prophylaxis in order to prevent venereal diseases and 'racial hygiene' (see Chapter 8 , p. 287). ${ }^{73}$ 


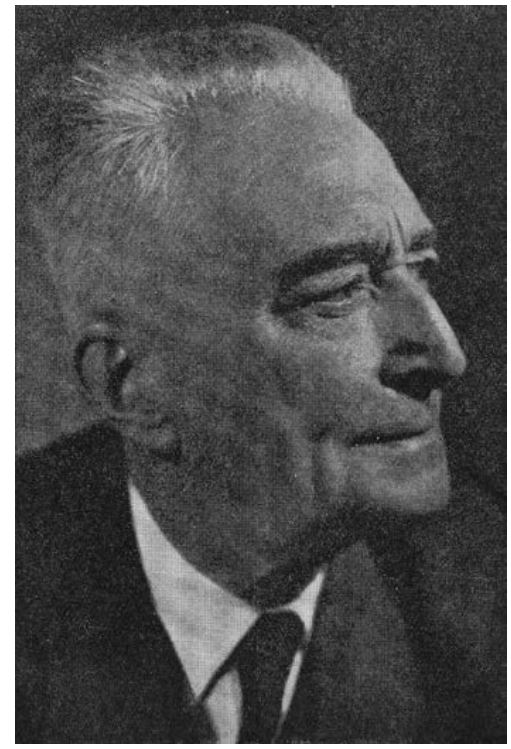

Figure 4.2 Portrait of René Sand. From an obituary notice connected with the International Congress of Social Work, 1953.

'Pour prospérer, la nation a besoin de toutes ses forces' ${ }^{74}$ This precept of the Belgian journal Revue d'engénique reveals how social medicine was regarded as the solution to many problems and being healthy was turned into a moral duty. Physicians therefore felt the urge to claim a greater role in defining social/health policies and protective laws. ${ }^{75}$ Indicative for the important role physicians played in Belgian society was the loi de défense sociale (9 April 1930), which allowed medical professionals to decide whether perpetrators of crimes were (ir)responsible because of their mental state. The purpose of this law was twofold: to provide those deemed insane with appropriate care and to protect society. In the first half of the twentieth century, social medicine further institutionalised, which resulted in a professionalisation of the healthcare system. In 1913, the Bulletin de l'Association belge de Médecine sociale was founded by the physician René Sand (Figure 4.2), providing a platform for knowledge exchange on social questions within the field of medicine and advocacy for civil servants, members of various medical boards, 'hygienist physicians' - in 1908, a one-year postgraduate training for 
physicians to obtain the degree of médecin hygiéniste was installed at the State Universities of Ghent and Liège - and other medical professionals. The journal responded to the urgency of coordinating the proliferation of measures, initiatives, councils and (often local) semi-public and private medical associations dealing with public healthcare and social medicine. A major influence was the growing importance of labour legislation for which physicians played both an advising as well as an executing role. ${ }^{76}$

Historians have argued that during the twentieth century the domain of industrial medicine and industrial diseases has been a scene of crucial struggles at the transnational level. ${ }^{77}$ Although Belgium, like France and the Netherlands, was sometimes left out of major discussions in the industrial hygiene section of the International Labour Organisation (ILO), it was strongly involved in many transnational social medical exchanges. ${ }^{78}$ Already near the end of the First World War, in spring 1918, the Belgian government sent a mission to the United States to study the organisation of labour, industrial production, social services and American society as a whole. The mission included the physician, social worker and internationalist René Sand. ${ }^{79}$ In 1919 René Sand published his views on the methods and aims of social work in the United States and Britain in order to stimulate the professionalisation of social work in Belgium. ${ }^{80}$ In the same year, together with Marie Derscheid, he started building the first Belgian school for the education of social workers (Ecole temporale de service social). In 1927, Sand translated and spread the work of Mary Richmond (What is Social Casework? An Introductory Description), which can be seen as a milestone in the professionalisation of social work. ${ }^{81}$

Professional social work stems from cognate scientific fields as social medicine and hygiene but also from a transnational knowledge exchange and the development of international organisations such as the Red Cross and platforms like the International Conferences of Social Work. ${ }^{82}$ Sand, who contributed to the resurgence of the Red Cross in Belgium after the First World War, was in 1921 appointed as general secretary of the Ligue des Sociétés de la Croix-Rouge, which stimulated the international cooperation in social work. Together with Alice Masarykova, Sand would play an important role in the establishment of the first Conférence internationale de Service social (Paris, 1928). ${ }^{83} \mathrm{He}$ also contributed to the 
international exchange of socio-medical knowledge as he travelled all over the world to lecture on social medicine. Already in the early 1920s, Sand belonged to a group of socio-medical professionals including Alfred Grotjahn, Ludwig Teleky, Alfons Fischer, Adolf Gottstein and Andrija Stampar who gave social medicine a scientific underpinning, stimulating the emergence of several university chairs for social medicine and the foundation of social hygienic academies. $^{84}$

Sand's initiatives are marked by a strong international scope, making him part of a wider trend identified by Saunier as the third circulatory regime, when social experts searched for universal norms and standards for social policies, professions and practices. They were strongly convinced that the universal spread of scientific social knowledge in general, and social medicine in particular, would lead to the 'well-being of humanity throughout the world'. The third regime was marked by the emergence of new international players with worldwide responsibilities such as the Office international d'Hygiène publique (OIHP, founded in 1907) and the aforementioned LNHO (founded in 1922). The League of Nations became an important actor in this field of social policy and many pre-war epistemic communities became further institutionalised. ${ }^{85}$ Collectively, they formed the diverse landscape of the international health work of the interwar period. ${ }^{86}$ Among these newly found international players, the Rockefeller groups particularly distinguished themselves with their contribution to the circulation of technical knowledge in the field of social hygiene and social medicine and financing of several new initiatives. ${ }^{87}$ With the support of the Rockefeller Foundation, Sand managed to create the first academic chair for history of medicine and social medicine at the Université Libre de Bruxelles (1945). ${ }^{88}$

\section{New activism, new public health systems?}

As it has been stipulated throughout this book, the medical history of Belgium in the twentieth century has been to some extent underexposed and this has also been the case with the history of social medicine and the public healthcare system. The public healthcare system was expanded and became more regularised and 
institutionalised in the wake of the Second World War. The Belgian government initiated an obligatory health insurance (Ziekte en Invaliditeitsvoorziening, ZIV 1944) which came into the hands of a new central government agency, the Rijksdienst voor Ziekteen Invaliditeitsverzekering. The national unity government also launched the so-called social pact, which bundled legislation on sickness and invalidity insurance, unemployment, pensions, child benefit and annual holiday for employees with the aim of improving the social security system and implementing the measures more efficiently (see Chapter 6, p. 224). ${ }^{89}$

Physicians were integrated in the system as mediators between the state, the patient and the health insurance agencies. They determined whether someone needed medical care (financial) support, but they were also expected to act as financial watchdogs to prevent abuse. Already from the start, ZIV caused a lot of problems. On the one hand, the law was full of gaps, leading to serious financial deficits. ${ }^{90}$ On the other hand, ZIV caused political controversy. The public healthcare system became politicised to a far greater extent than before. In Belgium several attempts were made to control the constantly expanding healthcare budget. ${ }^{91}$ As it had been the case everywhere in Europe in the period after 1960, the Belgian public health system was strongly questioned, leading to continuous political debate about the healthcare system's sustainability. ${ }^{92}$ Western healthcare systems were facing spiralling costs that needed to be kept within reasonable limits without losing the principle of distributive justice in the welfare state. ${ }^{93}$ But also the relation between the physicians as a professional group and the government became at times tense due to debates on the efficiency of medical service, savings in costs or the negations of the physicians' fees.

The postcolonial period is characterised by policies of efficiency and privatisation. At the same time, the field of social medicine took a global dimension thanks to initiatives launched by WHO, and planetary debates and actions concerning public health ignited by social movements and INGOs. ${ }^{94}$ Global health implies the consideration of the health needs of people of the whole planet above the concerns of particular nations. The term 'global' is also associated with the growing importance of actors beyond governmental or intergovernmental organisations and agencies, for example the media, internationally influential foundations, non-governmental 
organisations (NGOs) and transnational corporations. ${ }^{95}$ The work of contemporary players of 'global' stature such as the microbiologist Peter Piot, who discovered the Ebola virus in the 1970s, or the world-renowned fertility expert Marleen Temmerman, is clearly rooted in the 'Belgian' context of social activism, although both soon widened the scope of their scholarly and social commitments, first to Africa and its most vulnerable citizens, and finally to the entire planet.

The Institute of Tropical Medicine in Antwerp in particular gave the children of May 1968 wings to support their solidarity with what was then called the 'Third World'. Their engagement was embedded in the broader activism of the emerging 'new' social movements of the 1970s, the Third World movement in particular. Development work meant exercising social commitment. In the Belgian medicine faculties of the 1970s, this was certainly not a central concern. The number of initiatives was rather limited and they were not really 'carried' by the corps of professors, only by a minority of socially driven scholars within the faculties. In the fall of 1976, Peter Piot moved to the village of Yambuku on the Congo River to investigate the outbreak of an unknown disease that caused high fever, diarrhoea and severe bleeding. Piot had joined the Institute of Tropical Medicine in Antwerp two years after graduating and he specialised in microbiology. ${ }^{96}$

In September 1976, a blue thermos flask from Kinshasa arrived at the Antwerp laboratory for microbiology, containing blood samples from a Flemish missionary sister. An electron microscope survey showed that the deadly disease was not a normal virus, but a giant worm structure that had never been observed before. The then twenty-seven-year-old Peter Piot, who had never visited Africa before, boarded a C-130 aircraft, and flew from the capital of Congo/ Zaire to the rainforest. His mission was to diagnose the mysterious virus in its local context and stop the epidemic. After three months of improvising on the spot, he succeeded in observing how the virus was transferred. The virus was named after a neighbouring river, the Ebola. Forty years later, the sociopolitical circumstances in which the Ebola virus thrives has hardly changed. Political destabilisation, a dysfunctional health system, superstition, denial, poverty: the classical curative approach with vaccines, medication, isolation and quarantine is not enough if political, social and cultural factors 
are not taken into account. In addition, international organisations such as WHO fail to safeguard universal human rights. When in the summer of 2014 a very serious Ebola epidemic again broke out in West Africa, WHO was only seriously alerted after two American citizens had been flown home in alarming conditions. Meanwhile, more than a thousand dead victims were counted in Africa. At that moment Peter Piot had acquired the moral authority to denounce this scandalous fact worldwide. ${ }^{97}$ In Piot's opinion, science cannot be separated from activism and politics.

In October 1983, six years after the discovery of the Ebola virus, Piot discovered more than fifty acquired immune deficiency syndrome (AIDS) victims - men and women - in the Mama Yemo Hospital in Kinshasa. This confirmed the hypothesis that the infection was also transmitted through heterosexual contacts. For Piot this was a eureka moment of tremendous importance. Project SIDA in Zaire - an American-Belgian-Zairian research mission - became the world's first international AIDS campaign. In the 1990s Piot made the move from medicine to international institutions 'to change the world'. He took leading positions in the International AIDS Society, the AIDS programmes of WHO and UNAIDS, of which he was the founding executive director, combining his work with the position of assistant secretary-general of the United Nations. In Belgium itself, AIDS had initially appeared as an 'imported' disease, which was thought to be limited to (American) homosexuals and Africans. As a result of this, as Hans Neefs has shown, AIDS policy first developed largely outside the established public health structures. It was a new terrain of public health that developed from below through the work of medical experts such as Piot and Jan Desmyter. These medical experts developed policies of testing (surveillance), AIDS education, contact tracing, etc. In the second half of the 1980s, grass-roots AIDS organisations succeeded in reframing AIDS as a wider public health problem, not limited to gay people. Politicians now followed in setting up campaigns on safe sex, tackling ideologically difficult questions of sexual morality. ${ }^{98}$

Marleen Temmerman, a gynaecologist, women's rights activist and professor at Ghent University, followed a similar course. In 1987 she went to Kenya in the context of an AIDS research project set up by Peter Piot at the Kenyatta National Hospital in Nairobi. There she examined if and how women and children could be infected 
with human immunodeficiency virus (HIV). In 1992, the year she returned to Ghent, she received 2.4 million ECU from the European Commission to build an institute. It was seed money for starting up the International Centre for Reproductive Health (ICRH), founded in 1994. The ICRH was anchored in Ghent, with branches in Kenya and Mozambique. More than twenty-five years later it has grown into one of the largest centres of excellence in the field of reproductive health in the world. It has projects on a range of issues such as AIDS, sexually transmitted diseases, contraception, abortion, family planning, maternal mortality, genital mutilation, women's and children's health and sexual violence. The centre's strength is the dynamic interaction between multidisciplinary science and development cooperation and the implementation of research results into policy. It is no coincidence that Temmerman has been involved in politics. She was a senator for the Flemish Socialist Party from 2007 to 2012. She believes that scholars have the moral duty of giving politicians a language to speak and ask the right questions about public health. The UN Sustainable Development Goals provide a good guideline. From 2012 to 2015 Temmerman was a director at WHO. Since 2015 she has returned to Kenya, where she is leading the Department of Obstetrics and Gynaecology at Aga Khan University and continues to address women's health issues through the Aga Khan Development Network. ${ }^{99}$

In conclusion, it is clear that Piot and Temmerman are part of a long-standing tradition of social and medical activism. The history of public health and social medicine was a dynamic process of interaction between policymakers, physicians, medical and other professionals (civil servants, teachers, publicists, etc.), on the one hand, and social activists and reform movements, on the other. Moreover, public health is also a process of negotiation between various medical professionals and other experts on the issues of what public health was supposed to be, how it could be studied and how it needed to be improved. Both Adolph Burggraeve and Victor Desguin illustrated that in this process of negotiation no clear distinction could be made between the state, private practitioners and physicians who were never neutral and did not only influence decision-making processes but also became politically engaged, as they conducted policies and became a cog in the machinery of government. Many early local urban initiatives were launched by 
both medical professionals (in the making) and statisticians, thus trying to identify and explore socio-economic determinants for disease outbreaks. ${ }^{100}$ Regarding the late nineteenth century, it has been observed that these local dynamics evolved towards more centralised actions targeting the containment of epidemics, thus resulting, in the course of the twentieth century, in the emergence of national medical policies that aimed at improving public health. ${ }^{101}$

At the same time, social and medical activists negotiated their theories and policies and exchanged their thoughts and practices in an increasingly globalising world. As Eijkman had already noticed, these dynamics in the nineteenth and twentieth century were barely restricted by the borders of the (Belgian) nation state. Therefore, we have argued that the emergence of public healthcare in Belgium cannot be seen apart from cross-border exchanges, scientific innovations, social reform ambitions, but also inter- and intra-imperial dynamics. A similar story can be told in regard to social reform, starting with the initiatives taken by urban philanthropic circles. These initiatives contributed to the institutionalisation of social action, the emergence of national social policies and the development of social legislation. With the rise of the modern welfare states in the course of the twentieth century and the internationalisation of social politics, the entanglement of social and medical policies became even stronger. The role the physician René Sand played in the professionalisation of social work clearly illustrated that in the early twentieth century no strict distinction between medicine, public healthcare and social welfare could be made. The changing circulatory regimes, scientific development and sociopolitical circumstances had a profound influence on the evolving concept of social medicine, but in essence public health and hygiene initiatives and locally rooted social activism remained closely intertwined. In this chapter we have shown that in Belgium sociopolitical interventions were more coordinated than argued before. Nineteenth-century Belgium has indeed predominantly been described as a nightwatchman state. But when hygienists and the like are approached as part of a (transnational) movement, we should nuance and even doubt this. Historians have shown that already in the early nineteenth century private and public actors tried to improve public hygiene and living conditions, increasingly seeking government support from the second half of the nineteenth century onwards. Especially at the local level, many social interventions and 
actions took place in nineteenth-century Belgium. Furthermore, recent studies have shown that locally active physicians and the like belonged to a wider (transnational) movement, transcending their professional and disciplinary borders. ${ }^{102}$ This is similar to the upcoming labour unions and health insurance funds, which were also firmly rooted in international epistemic communities. ${ }^{103}$

\section{Notes}

1 Pieter Hendrik Eijkman, L'internationalisme médical (Amsterdam: F. van Rossen, 1910); Warden Boyd Rayward, Information Beyond Borders: International Cultural and Intellectual Exchange in the Belle Epoque (London: Ashgate, 2014), 204.

2 François de Torday, Compte rendu du XVIe Congrès international de Médecine (Budapest: Franklin-Tarsulat, 1909).

3 Maryinez Lyons, The Colonial Disease: A Social History of Sleeping Sickness in Northern Zaire, 1900-1940 (Cambridge, UK: Cambridge University Press, 1992), 76-136, 281; Myriam Mertens and Guillaume Lachenal, "The history of "Belgian" tropical medicine from a crossborder perspective', Revue belge de Philologie et d'Histoire, 90 (2012), 1249-72.

4 Stéphane Frioux, 'Sanitizing the city: the transnational work and networks of French sanitary engineers, 1890s-1930s', in Shaping the Transnational Sphere: Experts, Networks and Issues from the 1840s to the 1930s, ed. Davide Rodogno, Bernhard Struck and Jakob Vogel (New York: Berghahn, 2015), 44-59; Viviane Claude, 'Technique sanitaire et réforme urbaine: l'Association Générale des Hygiénistes et Techniciens Municipaux 1905-1920', in Laboratoires du nouveau siècle. La 'nébuleuse réformatrice' et ses réseaux en France 18801914, ed. Christian Topalov (Paris: EHESS, 1999), 269-98.

5 Joris Vandendriessche, Medical Societies and Scientific Culture in Nineteenth-Century Belgium (Manchester: Manchester University Press, 2018).

6 Hans Neefs, Between Sin and Disease: The Social Fight against Syphilis and AIDS in Belgium (1880-2000) (Saarbrücken: LAP Lambert, 2010).

7 Dorothy Porter, 'Stratification and its discontents: professionalization and conflict in the British public health service, 18481914', in A History of Education in Public Health: Health That Mocks the Doctors' Rules, ed. Elisabeth Fee and Roy M. Acheson (Oxford: Oxford University Press, 1991), 83-113. 
8 Christophe Charle, Jürgen Schriewer and Peter Wagner, Transnational Intellectual Networks: Forms of Academic Knowledge and the Search for Cultural Identities (Frankfurt: Campus, 2004); Davide Rodogno, Bernhard Struck and Jakob Vogel (eds), Shaping the Transnational Sphere: Experts, Networks, and Issues the 1840s to the 1930s (New York: Berghahn, 2015).

9 Daniel Laqua, Christophe Verbruggen, Gita Deneckere, PierreYves Saunier, Timothy Baycroft and Martin Conway, 'Beyond Belgium: encounters, exchanges and entanglements, 1900-1925', Journal of Belgian History-Revue belge d'Histoire contemporaineBelgisch Tijdschrift voor Nieuwste Geschiedenis, 43:4 (2013), 148-63.

10 Porter, 'Stratification and its discontents'.

11 Karel Velle, De nieuwe biechtvaders: de sociale geschiedenis van de arts in België (Leuven-Amsterdam: Kritak-Meulenhof, 1991).

12 Liesbet Nys, Henk De Smaele, Jo Tollebeek and Kaat Wils (eds), De zieke natie: over de medicalisering van de samenleving, 1860-1914 (Groningen: Historische Uitgeverij, 2002); Peter Conrad and Valerie Leiter (eds), Health and Health Care as Social Problems (Lanham, MD: Rowman \& Littlefield, 2003); Peter Conrad, The Medicalization of Society: On the Transformation of Human Conditions into Treatable Disorders (Baltimore, MD: Johns Hopkins University Press, 2008); Frank Huisman and Harry Oosterhuis (eds), Health and Citizenship: Political Cultures of Health in Modern Europe (London: Routledge, 2016).

13 Heidi Rimke and Alan Hunt, 'From sinners to degenerates: the medicalization of morality in the 19th century', History of the Human Sciences, 15:1 (2002), 59-88.

14 Lutz Raphael, 'Die Verwissenschaftlichung des Sozialen als methodische und konzeptionelle Herausforderung für eine Sozialgeschichte des 20. Jahrhunderts', Geschichte und Gesellschaft, 22:2 (1996), 165-93.

15 Jasmien van Daele and Christian Müller, 'Peaks of internationalism in social engineering: a transnational history of international social reform associations and Belgian agency, 1860-1925', Revue belge de Philologie et d'Histoire, 90:4 (2012), 1297-319; Thomas D'haeninck, Nico Randeraad and Christophe Verbruggen, 'Visualizing longitudinal data: rooted cosmopolitans in the Low Countries, 1850-1914', CEUR Workshop Proceedings, 1399 (2015), 116-21 (First Conference on Biographical Data in a Digital World, CEUR WS, 2015).

16 Scott Frickel and Neil Gross, 'A general theory of scientific/intellectual movements', American Sociological Review, 70:2 (2005), 204-32.

17 Pierre-Yves Saunier, 'Les régimes circulatoires du domaine social 1800-1940: projets et ingénierie de la convergence et de la différence', Genèses, 71:2 (2008), 4-25. 
18 Charle et al., Transnational Intellectual Networks; Rodogno et al., Shaping the Transnational Sphere.

19 Saunier, 'Les régimes circulatoires', 20.

20 Eckhardt Fuchs, 'The creation of new international networks in education: the League of Nations and educational organizations in the 1920s', Paedagogica Historica, 43:2 (2007), 199-209; Van Daele and Müller, 'Peaks of internationalism in social engineering', 1311-15.

21 As argued by $\mathrm{Hu}$ and Manning, a new global model of privatisation emerged the 1980s. Aiqun Hu and Patrick Manning, 'The global social insurance movement since the 1880s', Journal of Global History, 5:1 (2010), 125-48.

22 Jean-Pierre Goubert, '1770-1830: La première croisade médicale', Historical Reflections/Réflexions Historiques, 9:1-2 (1982), 3-13; Karel Velle, 'Medisch-topografisch en epidemiologisch onderzoek in België sinds het laatste kwart van de 18de eeuw tot ca. 1850: een bijdrage tot de sociale geschiedenis', Handelingen van de Koninklijke Zuid-Nederlansche Maatschappij voor Taal- en Letterkunde en Geschiedenis, 38 (1984), 209-29.

23 Porter, 'Stratification and its discontents'.

24 Michel Foucault, Anne Thalamy and Blandine Barret-Kriegel, Les machines à guérir: aux origines de l'hôpital moderne (Brussels: Mardaga, 1979), 7-18.

25 Karel Velle, 'Arts, geneeskunde en samenleving: medicalisering in België in de 19de en de 20ste eeuw' (PhD diss. Rijksuniversiteit Gent, 1987-88), 1047.

26 Ibid., 61-85. Velle also refers to Foucault et al., Les machines à guérir.

27 Velle, 'De misdaad als kwaal', 332-55; Conrad and Leiter, Health and Health Care as Social Problems; Conrad, The Medicalization of Society.

28 Joris Vandendriessche, 'Arbiters of science: expertise in public health in nineteenth-century Belgian medical societies', in Scientists' Expertise as Performance: Between State and Society, 1860-1960, ed. Joris Vandendriessche, Evert Peeters and Kaat Wils (London: Pickering \& Chatto, 2015), 31-48, at 33-6.

29 Karel Velle, 'Het verenigingsleven van de Belgische geneesheer', Annales de la Société belge d'histoire des hôpitaux et de la santé publique, 26-7 (1988-89), 47-118; Joris Vandendriessche and Kaat Wils, 'Een traject van onderhandeling. Hygiënisme als wetenschap, Antwerpen 1880-1900', BMGN: Low Countries Historical Review, 128:3 (2013), 3-28.

30 Vandendriessche, 'Arbiters of science', 34.

31 Veronique Deblon and Pieter Huistra, 'Het geheim van de anatoom: Adolphe Burggraeve en de ontwikkeling van de Belgische anatomie 
in de negentiende eeuw', Studium, 9:4 (2017), 202-16; Veronique Deblon, 'Adolphe Burggraeve en de schoonheid van de dood', in Post-Mortem. Vesalius tussen kunst en wetenschap, ed. Marjan Doom (Ghent: Gents Universiteitsmuseum, 2015), 63-5; Marjan Doom, Het museum van de twijfel. Een bescheiden manifest van een wetenschapscurator (Ghent: Academia Press, 2020), 77-84.

32 This association was named after the charismatic professor François Huet. For a short period it was the meeting place in Ghent for freethinkers to discuss philosophical, political and social problems. E. C. Coppens, 'La Société Huet. Tussen revolutie en reaktie', Handelingen der Maatschappij voor Geschiedenis en Oudheidkunde te Gent, 26:1 (1972), 131-51.

33 Vandendriessche, 'Arbiters of science', 33-6.

34 Daniel Mareska and Jean-Julien Heyman, Enquête sur le travail et la condition physique et morale des ouvriers employés dans les manufactures de coton, à Gand (Gand: Gyselynck, 1845).

35 Vandendriessche, 'Arbiters of science', 34-5.

36 Bart Vos, 'De Bataviawijk: studie van een arbeidersbuurt in de eerste generatie (1836-1914)' (Master's diss., Rijksuniversiteit Gent, 1985).

37 Adolphe Pauli and Auguste Wagener, Le nouvel Institut des sciences à Gand (Gand: Hoste, 1892).

38 Doreen Gaublomme, 'Doctrinairen en progressisten tijdens de 19de eeuw', in Het Liberalisme in België. Tweehonderd jaar geschiedenis, ed. Hervé Hasquin and Adriaan Verhulst (Brussels: Uitgeverij Delta, 1989), 201-8.

39 Joris Vandendriessche, 'Medische expertise en politieke strijd. De dienst medisch schooltoezicht in Antwerpen, 1860-1900', Stadsgeschiedenis, 6:2 (2011), 113-28.

40 Kathleen Devolder, Gij die door 't volk gekozen zijt ... De Gentse gemeenteraad en haar leden 1830-1914 (Ghent: Maatschappij voor Geschiedenis en Oudheidkunde, 1994).

41 Oliver MacDonagh, 'IV. The nineteenth-century revolution in government: a reappraisal', Historical Journal, 1:1 (1958), 52-67; Roy MacLeod, Government and Expertise: Specialists, Administrators, and Professionals (Cambridge, UK: Cambridge University Press, 1988); David S. Barnes, The Great Stink of Paris and the NineteenthCentury Struggle against Filth and Germs (Baltimore, MD: Johns Hopkins University Press, 2006).

42 Vandendriessche and Wils, 'Een traject van onderhandeling'.

43 Saunier, 'Les régimes circulatoires', 4-25.

44 Eckhardt Fuchs, 'Educational sciences, morality and politics: international educational congresses in the early twentieth century', Paedagogica Historica, 40:5-6 (2004), 758. 
45 Carmen van Praet, 'Liberale hommes-orchestres en de sociale kwestie in de negentiende eeuw. Tussen lokaal en internationaal' (PhD thesis, Ghent University, 2015), 141-6.

46 Ibid., 144.

47 Margaret E. Keck and Kathryn Sikkink, 'Transnational advocacy networks in international and regional politics', International Social Science Journal, 51:159 (1999), 88-101.

48 Robert Halleux, Geneviève Xhayet, Pascal Pirot, Jan Vandersmissen and Rik Raedschelders, Tant qu'il y aura des chercheurs. Science et politique en Belgique de 1772 à 2015 (Liège: Luc Pire, 2015), 44-8; Robert Halleux, Jan Vandersmissen, Andrée Despy-Meyer and Geert Vanpaemel (eds), Geschiedenis van de wetenschappen in België 1815-2000 (Brussels: Dexia Bank-La Renaissance du Livre, 2001), 289-305.

49 Halleux et al., Tant qu'il y aura des chercheurs, 44-8.

50 Alan J. Rocke, Image and Reality: Kekulé, Kopp, and the Scientific Imagination (Chicago: University of Chicago Press, 2010); Halleux et al., Geschiedenis van de wetenschappen in België 1815-2000, 289-305.

51 Velle, 'Arts, geneeskunde en samenleving', 57; Halleux et al., Tant qu'il y aura des chercheurs.

52 Sofie Onghena, 'Altruïstisch ambtenaar of heroïsch genie? Het gepropageerde beeld van provinciale en academische directeurs van bacteriologische laboratoria in België (ca. 1900-1940)', Studium, 2:4 (2009). On government laboratories in Belgium, see Lyvia Diser, Wetenschap op de proef. Laboratoria in het Belgisch overheidsbeleid, 1870-1940 (Leuven: Leuven University Press, 2016).

53 About prison doctors, see chap. 3 in Amandine Thiry's forthcoming doctoral thesis (UCLouvain/UGent). Her research project is entitled: "Confinement as social utopia. "Belgian" reformers and transnational ideas on prison'.

54 Vandendriessche, Medical Societies and Scientific Culture, 181-96; Liesbet Nys, 'Nationale plagen. Hygiënisten over het maatschappelijk lichaam', in Nys et al., De zieke natie, 220-41.

55 Evert Peeters and Kaat Wils, 'Ambivalences of liberal health policy: lebensreform and self-help medicine in Belgium, 1890-1914', in Huisman and Oosterhuis, Health and Citizenship, 101-17.

56 Ilse De Buyser, 'Bijdrage tot de geschiedenis van het medisch schooltoezicht in België. Van de eerste initiatieven tot de inrichting van het verplicht MST, 1874-1914' (master's diss., KU Leuven, 1995); Karel Velle, 'De schoolgeneeskunde in België (1850-1940)', Geschiedenis der Geneeskunde, 5 (1998), 354-66. 
57 Karel Velle, 'Eugène Dorothé Janssens: ambtenaar en medischstatisticus', in Er is leven voor de dood. Tweehonderd jaar gezondheidszorg in Vlaanderen, ed. Jan De Maeyer, Lieve Dhaene, Karel Velle and Gilbert Hertecant (Kapellen: Pelckmans, 1998), 111-13.

58 Joris Vandendriessche, 'Medische expertise en politieke strijd. De dienst medisch schooltoezicht in Antwerpen, 1860-1900', Stadsgeschiedenis, 6:2 (2011), 113-28.

59 Nico Randeraad, 'Triggers of mobility: international congresses (1840-1914) and their visitors', in Mobility and Biography, ed. Sarah Panter (Berlin: De Gruyter, 2015), 69-71.

60 Vandendriessche, 'Medische expertise en politieke strijd', 124-6.

61 Liesbet Nys, 'De grote school van de natie. Legerartsen over drankmisbruik en geslachtsziekten in het leger (circa 1850-1950), BMGN: Low Countries Historical Review, 115:3 (2000), 392-425.

62 Marie Parent, Le rôle de la femme dans la lutte contre l'alcoolisme (Brussels: Ligue patriotique contre l'alcoolisme, 1892).

63 Martine Timmerman, 'De sociale ernst van het alkoholisme en de mobilisatie voor drankbestrijding vanaf het laatste kwart van de 19de eeuw' (master's diss., Ghent University, 1981); Maurice De Vroede, 'Primary education and the fight against alcoholism in Belgium at the turn of the century', History of Education Quarterly, 25:4 (1985), 483-97.

64 Albert Duchesne, 'Premier centre médical de l'Afrique noire: le 'sanitarium' du Docteur Allart à Boma (1883)', in Le Centenaire de l'Etat Indépendant du Congo: recueil d'études = Bijdragen over de honderdste verjaring van de Onafhankelijke Kongostaat (Brussels: Académie royale des Sciences d'Outre-Mer-Koninklijke Academie voor Overzeese Wetenschappen, 1988), 313-22; J. André, J. Burke, J. Vuylsteke and H. van Balen, 'Evolution of health services', in Health in Central Africa since 1885: Past, Present and Future, ed. P. G. Janssens, M. Kivits and J. Vuylsteke (Brussels: King Baudouin Foundation, 1997), vol. 1, 89-158.

65 Michael A. Osborne, The Emergence of Tropical Medicine in France (Chicago: University of Chicago Press, 2014); Ryan Johnson, Tropical Medicine and Imperial Power: Science, Hygiene and Health in the Late British Empire (London: I. B. Tauris, 2014).

66 Deborah J. Neill, Networks in Tropical Medicine: Internationalism, Colonialism, and the Rise of a Medical Specialty, 1890-1930 (Palo Alto, CA: Stanford University Press, 2012), 1-43; Jan Vandersmissen, Koningen van de wereld: Leopold II en de aardrijkskundige beweging (Leuven: Acco, 2009), 251-84; Pieter G. Janssens, Maurice Kivits and Jacques Vuylsteke (eds), Médecine et hygiène en Afrique Centrale: de 1885 à nos jours (Brussels: Fondation Roi Baudouin, 1992), 1-61. 
67 Jérôme Becker, 'Gymnases d'exploration et de colonisation. Projet présenté par l'auteur au Congrès d'Hygiène et d'acclimatement de Berlin (1886)', in La vie en Afrique ou trois ans dans l'Afrique centrale, ed. Jérôme Becker (Paris: J. Lebègue \& Cie, 1887), vol. 2, 489-500.

68 Jan Vandersmissen, "De "Manuel du voyageur et du résident au Congo" en de voorbereiding op het dagelijkse leven in de Onafhankelijke Congostaat op het einde van de 19de eeuw', in Quotidiana. Huldealbum Dr. Frank Daelemans, ed. Ria Jansen-Sieben, Marc Libert and André Vanrie (Brussels: Archief-en bibliotheekwezen in België, 2012), 413-36.

69 Pedro Monaville, “"Conseils aux partants": Une lecture politique des manuels d'hygiène coloniale publiés en Belgique (1895-1950)', Journal of Belgian History: Revue belge d'Histoire contemporaine-Belgisch Tijdschrift voor Nieuwste Geschiedenis, 36:1-2 (2012), 97-125.

70 Mertens and Lachenal, 'The history of "Belgian" tropical medicine', 1262-9.

71 Sokhieng Au, 'Medical orders: Catholic and Protestant missionary medicine in the Belgian Congo (1880-1940)', BMGN: Low Countries Historical Review, 132:1 (2017), 62-82.

72 Translation from French, see Petre Trisca, Les médecins sociologues et hommes d'Etat (Paris: Alcan, 1923), 14-15.

73 Velle, 'Arts, geneeskunde en samenleving', 1054; Raf De Bont, 'Meten en verzoenen. Louis Vervaeck en de Belgische criminele antropologie (circa 1900-1940)', Cahiers d'histoire du temps présent, 9 (2001), 63-104.

74 The Revue d'engénique was founded in 1921 by the physicians René Sand, George Boulenger, Albert Govaerts, Rulot and the judge Wets: Velle, 'Arts, geneeskunde en samenleving', 49.

75 Velle, 'Arts, geneeskunde en samenleving', 1057.

76 Ibid., 1087.

77 Thomas Cayet, Paul-André Rosental and Marie Thébaud-Sorger, 'How international organisations compete: occupational safety and health at the ILO, a diplomacy of expertise', Journal of Modern European History, 7:2 (2009), 195.

78 Ibid., 179.

79 Michaël Amara, 'La propagande belge et l'image de la Belgique aux Etats-Unis pendant la Première Guerre mondiale', Journal of Belgian History-Revue belge d'Histoire contemporaine-Belgisch Tijdschrift voor Nieuwste Geschiedenis, 30:1-2 (2000), 173-226, at 200-2.

80 René Sand, La bienfaisance d'hier et la bienfaisance de demain (Brussels: Impr. L. Vogels, 1919); Kerstin Eilers, 'René Sand (18771953) and his contribution to international social work, IASSWpresident 1946-1953', Social Work and Society, 5:1 (2007), 102-9. 
81 Alain Anciaux, Le docteur René Sand ou la culture des valeurs humaines (Brussels: Université Libre de Bruxelles, 1988); Alain Anciaux, René Sand: un médecin belge humaniste ou la vocation de la médecine sociale (Brussels: Université Libre de Bruxelles, 1988).

82 Eilers, 'René Sand'.

83 Ibid.; Sabine Hering-Calfin and Berteke Waaldijk, History of Social Work in Europe (1900-1960): Female Pioneers and Their Influence on the Development of International Social Organizations (New York: Springer Science and Business Media, 2012), 119-28.

84 Iris Borowy, Coming to Terms with World Health: The League of Nations Health Organisation 1921-1946 (Frankfurt am Main: Peter Lang, 2009), 21; Patrick Zylberman, 'Fewer parallels than antitheses: René Sand and Andrija Stampar on social medicine, 1919-1955', Social History of Medicine, 17:1 (2004), 77-92.

85 Fuchs, 'The creation of new international networks in education'; Van Daele and Müller, 'Peaks of internationalism in social engineering'.

86 Iris Borowy, 'The League of Nations Health Organization: from European to global health concerns', in International and Local Approaches to Health and Health Care, Bergen, University of Bergen, ed. Astri Andresen, William H. Hubbard and Teemu Ryymin (Oslo: Novus Press, 2010), 11-30.

87 Saunier, 'Les régimes circulatoires'; John Farley, To Cast Out Disease: A History of the International Health Division of the Rockefeller Foundation (1913-1951) (New York: Oxford University Press, 2004).

88 Eilers, 'René Sand'.

89 Karel Veraghtert and Brigitte Widdershoven, Twee eeuwen solidariteit. De Nederlandse, Belgische en Duitse ziekenfondsen tijdens de negentiende en twintigste eeuw (Amsterdam: Aksant, 2002); Ineke Meul, 'De professionalisering van het medisch-specialistisch beroep in het kader van de verplichte Ziekte-en invaliditeitsverzekering in België (1944-2014)' (PhD thesis, Universiteit Antwerpen, 2016).

90 Meul, 'De professionalisering', 111.

91 Ibid.

92 Huisman and Oosterhuis, Health and Citizenship.

93 Frank Huisman, Joris Vandendriessche and Kaat Wils, 'Blurring boundaries: towards a medical history of the twentieth century', BMGN: Low Countries Historical Review 132:1 (2017), 11.

94 See Hu and Manning, 'The global social insurance movement since the 1880s'.

95 Theodore M. Brown, Marcos Cueto and Elizabeth Fee, 'The World Health Organization and the transition from "international" to "global" public health', American Journal of Public Health, 96:1 (2006), 62-72. 
96 Gita Deneckere, Uit de ivoren toren: 200 jaar Universiteit Gent (Ghent: Tijdsbeeld, 2017), 277-9.

97 Peter Piot, No Time to Lose: A Life in Pursuit of Deadly Viruses (New York: W. W. Norton \& Company, 2012).

98 Neefs, Between Sin and Disease, 219-96.

99 Deneckere, Uit de ivoren toren, 286-7.

100 Vandendriessche and Wils, 'Een traject van onderhandeling'.

101 Velle, De nieuwe biechtvaders; Elisabeth Bruyneel, De Hoge Gezondheidsraad (1849-2009): Schakel tussen wetenschap en volksgezondheid (Leuven: Peeters, 2009).

102 Van Praet, 'Liberale hommes-orchestres'.

103 Van Daele and Müller, 'Peaks of internationalism in social engineering', 1311-15.

\section{Selected bibliography}

Cayet, Thomas, Rosental, Paul-André and Thébaud-Sorger, Marie, 'How international organisations compete: occupational safety and health at the ILO, a diplomacy of expertise', Journal of Modern European History, 7:2 (2009), 174-96.

Neefs, Hans, Between Sin and Disease: The Social Fight against Syphilis and AIDS in Belgium (1880-2000) (Saarbrücken: LAP Lambert, 2010).

Neill, Deborah J., Networks in Tropical Medicine: Internationalism, Colonialism, and the Rise of a Medical Specialty, 1890-1930 (Palo Alto, CA: Stanford University Press, 2012).

Nys, Liesbet, De Smaele, Henk, Tollebeek Jo and Wils, Kaat (eds), De zieke natie: over de medicalisering van de samenleving, 1860-1914 (Groningen: Historische Uitgeverij, 2002).

Peeters, Evert and Wils, Kaat, 'Ambivalences of liberal health policy: lebensreform and self-help medicine in Belgium, 1890-1914', in Frank Huisman and Harry Oosterhuis (eds), Health and Citizenship. Political Cultures of Health in Modern Europe (London: Pickering \& Chatto, 2015), 101-17.

Saunier, Pierre-Yves, 'Les régimes circulatoires du domaine social 18001940: projets et ingénierie de la convergence et de la différence', Genèses, 71:2 (2008), 4-25.

van Daele, Jasmien and Müller, Christian, 'Peaks of internationalism in social engineering: a transnational history of international social reform associations and Belgian agency, 1860-1925', Revue belge de Philologie et d'Histoire, 90:4 (2012), 1297-319. 
Vandendriessche, Joris, 'Arbiters of science: expertise in public health in nineteenth-century Belgian medical societies', in Joris Vandendriessche, Evert Peeters and Kaat Wils (eds), Scientists' Expertise as Performance: Between State and Society, 1860-1960 (London: Pickering \& Chatto, 2015), 31-48.

Velle, Karel, 'Arts, geneeskunde en samenleving: medicalisering in België in de 19de en de 20ste eeuw' (PhD thesis, Ghent University, 1988).

Zylberman, Patrick, 'Fewer parallels than antitheses: René Sand and Andrija Stampar on social medicine, 1919-1955', Social History of Medicine, 17:1 (2004), 77-92. 